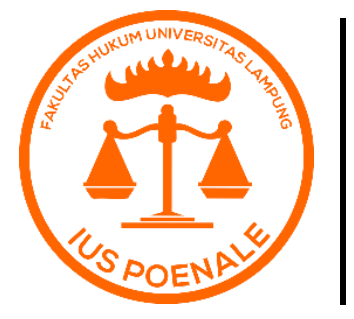

IUS Poenale

\title{
Criminal Law Enforement Towards Journalists That Spread False News
}

\author{
Rizky Efriliandis \\ efriliandisrizky@gmail.com \\ The Faculty of Law, Universitas Lampung
}

Submitted: 7 December 2020; Reviewed: 29 December 2020; Accepted: 18 February 2021.

\section{Article's Information}

\section{Abstract}

Key Word: Journalists; Law;
Enforcement; News.

DOI:

https://doi.org/10.25041/ip.v2.i1.2159
The press in performing its functions can not be separated from all acts of fraud and irregularities committed by the subjects of the press both the public, the press (journalists, media, press council, etc.), even the government. Criminal law has two main elements namely, the first is the existence of a norm, which is a prohibition or order (rule). Second, the existence of sanctions for violations of the norm in the form of threats with criminal law. This research aims: 1) to analyze criminal law enforcement against journalists who make the wrong coverage. 2) To analyze the legal liability system for journalists who make the wrong coverage. 3) To analyze the efforts that can be taken due to wrong press reporting. the research method used is qualitative analysis, data sources obtained through interviews, observations, documentation and literature relating to the title of the study. If the elements of crime committed by journalists are fulfilled egal liability mechanism for journalists who make the wrong reporting, then the legal liability is resolved through the mechanism of the Press Law by referring to the Press Council as the party authorized by law. Enforcement of criminal law against journalists who make scientific publications are based on journalists that have violated provisions which are guidelines for writing news an caused impact 
on parties who are disadvantaged by the publication. Efforts that can be taken as a result of wrong press reporting can be done by making complaints at the Press Council which will resolve public complaints on cases related to press reporting to immediately revoke, rectify, and correct false and inaccurate news accompanied by an apology to the reader, listener, and or viewer.There is an urgency for control by the Head of Newspapers in applying the journalistic code of ethics to journalists is carried out continuously. Moreover, the journalistic code of ethics needs to be a guideline for conducting news breeding. To the public, they should not hesitate to report to the Press Council if there is false publication of the news.

\section{A. Introduction}

The press is a tool to implement the principle of freedom or independence. The press is part of the means for society to spark ideas and has a principal role in a government that has the principle of freedom or independence. ${ }^{1}$ An independent and responsible press has a beneficial contribution to a democratic nation. ${ }^{2}$ Press issues are a very significant part of the problem in Indonesia. Press issues are related to the freedom to express ideas, provide and obtain information, leading to people's sovereignty and symbolizing essential civilian authority to create independent joint activities within the Republic of Indonesia. Knowing the dignity of democracy, it has been stated and is listed in parts of the 1945 Constitution of the Republic of Indonesia. ${ }^{3}$ Thus, it is certain that the government has legalized the right to state its intentions, independence to assume as a real attempt by the government to be free based on applicable regulations. ${ }^{4}$ But presumably, it is important to know that journalists only obey the national regulations. The basis for consensus before the regulations continues to run all the people who are in the Indonesian government, including journalists, who are the soul of the press. ${ }^{5}$ The basis of equality in front of the system is also arranged with certainty which is

${ }^{1}$ Dahlan Surbakti, "PERAN DAN FUNGSI PERS MENURUT UNDANG-UNDANG PERS TAHUN 1999 SERTA PERKEMBANGANNYA Dahlan Surbaktil," Jurnal Hukum PRIORIS, vol. 5, May 18, 2016, https://rijurnal.lemlit.trisakti.ac.id/prioris/article/view/396.

${ }^{2}$ Triya Indra Rahmawan, "KARAKTERISTIK PRODUK HUKUM PERS DAN PROSPEK KONSOLIDASI DEMOKRASI," WASKITA: Jurnal Pendidikan Nilai Dan Pembangunan Karakter 2, no. 2 (July 1, 2017): 1-16, https://doi.org/10.21776/ub.waskita:jurnalpendidikannilaidanpembangunankarakter.2018.002.02.1.

${ }^{3}$ Abdul Halik, "ATMOSFER KEBEBASAN PERS (ANTARA HUKUM, ETIKA, DAN PROFESIONALISME WARTAWAN)," Jurnal Jurnalisa: Jurnal Jurusan Jurnalistik 6, no. 1 (June 3, 2020), https://doi.org/10.24252/JURNALISA.V6I1.13667.

${ }^{4}$ Nur Aisyah Siddiq, "PENEGAKAN HUKUM PIDANA DALAM PENANGGULANGAN BERITA PALSU (HOAX) MENURUT UNDANG-UNDANG NO.11 TAHUN 2008 YANG TELAH DIRUBAH MENJADI UNDANG-UNDANG NO.19 TAHUN 2016 TENTANG INFORMASI DAN TRANSAKSI ELEKTRONIK," $\begin{array}{llllll}\text { LEX ET } & \text { SOCIETATIS, } & \text { vol. } & \text { December } & 22, & 2017 \text {, }\end{array}$ https://ejournal.unsrat.ac.id/index.php/lexetsocietatis/article/view/18485.

${ }^{5}$ Irman Syahriar, "FUNGSI PERS SEBAGAI PENYEBARAN INFORMASI DALAM PENEGAKAN HUKUM DI INDONESIA,” LEGALITAS 4, no. 2 (January 15, 2020): 19-35, https://doi.org/10.31293/LG.V4I2.4460. 
contained in the basis of state law and has been separated. Therefore, journalists are obliged to obey and obey the criminal regulations.

The main problem of media mass is that publicity is used in order to commit a lie or slander a person or institution and does not have mass media in the preaching, has a share of the culprit and part of the lie which contains parts of the criminal act. ${ }^{6}$ So the concern to this is that law must be used for individuals who intend journalistic law violation by using public media through a forum. In this regard, journalists' independence is used to report by implementing responsibility and professionalism, even though there are mistakes in writing that should not be punished.

Journalists in implementing their functions and duties cannot be separated from various mistakes made in the news. Criminal provisions (law) have two basic elements, first, the existence of a regulation, namely an act that is not allowed (rules). Second, there is a penalty for violating the act in the form of a criminal sanction. ${ }^{7}$ The loading of criminal sanctions cannot be carried out in full because law enforcers have limitations inherent in the norms of formal criminal law and material criminal law. The provision of speech sanctions makes the performance of police and prosecutors better and shows a vision for the future, for example, applying criminal sanctions in order to create a situation for the common interest. The view of law being the highest regulation is not interpreted as something that views the constitution only as a rule, but it must be seen that there are aspects of the supremacy of justice that need to be fulfilled. Regarding Judicial Powers as stated in Article 5 paragraph (1) of Law Number 48 of 2009, such work procedures become the embodiment of a criminal justice mechanism based on the contribution of society. Moreover, it is realized in the form of excellent service and executed genuinely. ${ }^{8}$

Based on the opinions of Muladi and Dwidja Priyatno quoted by Eddy Rifai explains: ${ }^{9}$ legalization of business entities responsibility as criminals is based as follows: (1) the directions of integralistic lessons or everything that balanced harmony and connection between individual interests and social interests, (2) the basic directions of kinship, which contains Article 33 of the 1945 Constitution, (3) to overcome anomie of success (success without rules), (4) to protect consumers, and (5) utilization of technology development.

However, it is important to recognize that not all media institutions in Indonesia implement a quality media that works professionally and responsible in cases. This action is important to monitor recalling that the society has not yet thoroughly reached the level of reason and logic. ${ }^{10}$ The sense of responsibility and professional character of media/press at work still need to be supervised because the media can greatly influence the psychology of society as a whole. $^{11}$

\footnotetext{
${ }^{6}$ Iin Rahmawati and Ruslan Abdul Gani, "PERTANGGUNGJAWABAN PIDANA TERHADAP DELIK PERS (Suatu Kajian Normatif)," Legalitas: Jurnal Hukum 1, no. 4 (May 9, 2017): 133-90, http://legalitas.unbari.ac.id/index.php/Legalitas/article/view/74.

${ }^{7}$ Mufti Nurlatifah, "POSISI UNDANG-UNDANG PERS INDONESIA DALAM EKOSISTEM MEDIA DIGITAL," Profetik: Jurnal Komunikasi 11, no. 1 (April 29, 2018): 71, https://doi.org/10.14421/pjk.v11i1.1289.

${ }_{8}^{8}$ Maroni, Rekonstruksi Birokrasi Peradilan Pidana Berbasis Pelayanan Publik Untuk Mewujudkan Keadilan, Lembaga Program Pascasarjana Undip, (2012), pg 9

${ }^{9}$ Eddy Rifai, 2014. Perspektif Pertanggungjawaban Pidana Korporasi Sebagai Pelaku Tindak Pidana Korupsi, Mimbar Hukum Fakultas Hukum Universitas Gadjah Mada,(2014), pg. 5

${ }^{10}$ Sandy Prasetya Makal, Syamsul Haling, and Andi Purnawati, "PERTANGGUNGJAWABAN PIDANA PELAKU TINDAK PIDANA PERS BERDASARKAN HAK JAWAB (STUDI KASUS DUA PUTUSAN PENGADILAN) CRIMINAL LIABILITY FOR CRIMINAL ACTS OF THE PRESS UNDER THE RIGHT OF RESPONSIBILITY (CASE STUDY OF TWO COURT JUDGMENTS)," Jurnal Kolaboratif Sains, vol. 1, September 15, 2019, https://doi.org/10.31934/JOM.V1I1.931.

${ }^{11}$ Sigit Surahman and Fuqoha Fuqoha, "MEKANISME PENYELESAIAN PELANGGARAN KODE ETIK JURNALISTIK PADA DEWAN PERS DI KOTA SERANG," LONTAR: Jurnal Ilmu Komunikasi 5, no. 2 (December 29, 2017): 51-64, https://doi.org/10.30656/lontar.v5i2.491.
} 
Media legal accountability is the deelneming criminal responsibility mechanism that can be seen in the form of inclusion or the waterfall accountability mechanism. ${ }^{12}$ There are two alternative solutions that can be done to take action against members of the press. First, it is resolved based on criminal or civil law depending on the problems. Secondly, solution is based on the Press Law which regulates responsibility through pre-determined of rights, responsibility, and correction. Problem identification in this research consist of: (1) The legal responsibility mechanism for journalists who acted in the wrong news has not been fully carried out in accordance with the procedure and (2) the process of resolving criminal acts against individuals who make wrong reporting rarely reaches the court stage. The reason is public ignorance in reporting the journalist's actions of false new even though it is prohibited by the law.

The research method is a case study type, which is the collection of data through in-depth interviews, observations, and documentation related to the problems to be reviewed. After the data has been collected and processed, the following activity is data analysis. The research used qualitative analysis, which is a way of describing the data obtained in the form of explanations and sentence descriptions. Furthermore, conclusions can be drawn inductively, namely a way of thinking from general matters and then drawing specific conclusions. From the conclusions that have been obtained, suggestions are given.

\section{B. Discussion}

\section{Legal Responsibility Mechanism towards Journalist that Spread False News}

Legal liability is an order related to legal obligations and legal responsibility (liability). ${ }^{13}$ A person who has responsibility in law for certain actions is subject to punishment in cases of acts that are contrary or against the law.

There are several criminal liability mechanisms. There are at least five legal responsibility mechanisms, namely:

a. Individual responsibility mechanism.

b. Corporation responsibility mechanism.

c. Corporate management responsibility mechanism.

d. Corporate responsibility mechanism with its corporate management simultaneously.

e. Individual waterfall responsibility mechanism.

Responsibility for journalists is regulated internally in relation to journalists' activities the responsibility of the journalist profession in relation to the Journalistic Code of Ethics is stated in a joint decree which is the legal basis for the mass media.

If in a press release written by a journalist there is a criminal allegation or assumption, thus the police investigator must examine them which according to the fictitious and successful accountability mechanism, the person in charge.

The fact that is a person in charge is asked to be a witness and the news by the police investigator is necessary, the examinations are open and the person in charge can come to be asked for clarification. In front of the police investigator, the person in charge is only able to inform the statement as long as the news is written. Outside of writing, the person in charge has no obligation to explain it.

\footnotetext{
${ }^{12}$ Raden Muhamad and Ibnu Mazjah, "TANGGUNGJAWAB PERS NASIONAL SEBAGAI SUBJEK HUKUM PIDANA DALAM PERSPEKTIF TANGGUNGJAWAB KORPORASI," Raden Muhamad Ibnu Mazjah $\begin{array}{lllllll}\text { Tanggungjawab Pers Nasional..., } & \text { vol. } & \text { 16, } & \text { July } & \text { 2018, }\end{array}$ https://journal.untar.ac.id/index.php/hukum/article/view/4527.

${ }^{13}$ Indah Lestari and Sri Endah Wahyuningsih, "PENEGAKAN HUKUM PIDANA TERHADAP PENGGUNA NARKOBA DI POLDA JATENG," Jurnal Hukum Khaira Ummah 12, no. 3 (September 15, 2017): 601-10, http://jurnal.unissula.ac.id/index.php/jhku/article/view/1889.
} 
Criminal responsibility is to apply punishment to the perpetrator because their actions violate prohibition to create a situation that can cause inconvenience in the community. ${ }^{14}$

Something that is accountable before the law is of course related to the system of crimes committed by someone who is against the rule of law. To hold a citizen accountable for violating what is not allowed, acts that violate the law are stated on the basis of the circumstances of the perpetrator and do not have to complete all the offense that violates the law and there are at least two valid evidence.

Therefore, negligence is positioned as the side of determining a legal act in subsequent crimes not merely as a moral element with respect to an act that violates the law. ${ }^{15}$ Humans are considered to have negligence as a matter of criminal liability. ${ }^{16}$ There are three forms of psychological condition of a person in carrying out criminal responsibility; first, understand that actions have consequences that can be caused; second, being aware that the act is prohibited; third, there is a determination regarding the ability of the action. ${ }^{17}$ The existing elements must be fulfilled first if you want to take action against any media person who reports wrongly, then the settlement process is completed based on the Press Law and through the Press Council which is an institution authorized by law.

\section{Criminal Law Enforcement against Individual Journalists that Spread False News}

Law enforcement has the aim of seeking justice. In addition, law enforcement aims at making society welfare as a whole. In essence, law enforcement is carried out accurately on any legal issues that must fulfill several aspects based on the objectives of law enforcement itself.

Law enforcement is not only useful for maintaining the balance of rules in society (restitutio in integrum), but also the legal mechanism makes the complexity of reality or facts that are basically absolute easier to master.

Based on the antinomic framework between the rules of actions that violate the law in the state provisions made by the government, the framework is used as a basis for legal preference. The basis for legal preference used is a legal basis that is specific and overrides general law. The Press Law is a specific legal basis of the Criminal Code. The determination of legislation as a legal basis of a specific nature does not determine the mechanism of criminal liability for the press against individuals who are suspected of committing criminal acts when carrying out their journalistic activities.

In connection with the preference for journalism legacy on the basis of criminal law, in general there are three opinions regarding the preferences of the Press Law against the basis of criminal law and legislation, first, Press legislation is not a law that is specific to the basis of criminal law, second, press legislation is a law that is specific in nature from the basis of criminal law and thirdly, press legislation is a separate legislative regime that must take precedence.

The Press Law is a lex specialis from the Criminal Code which is based on the following arguments: first, freedom of the press is one of the prerequisites for a legal state and the embodiment of humans has inherent rights and has been borne with all the provisions and rules to which the law applies, also a special ethic that governs the lifestyle of the press itself. Law and ethics that govern the press is the journalistic legislation of all press regulations, so

\footnotetext{
${ }^{14}$ Muhaimin Muhaimin, "Restoratif Justice Dalam Penyelesaian Tindak Pidana Ringan," Jurnal Penelitian Hukum De Jure 19, no. 2 (June 26, 2019): 185, https://doi.org/10.30641/dejure.2019.v19.185-206.

${ }^{15}$ Chairul, Dari Tiada Pidana Tanpa Kesalahan Menuju Kepada Tiada Pertanggungjawaban Pidana Tanpa Kesalahan,Jakarta: Kencana Prenada Media, (2006), pg. 4.

${ }^{16}$ Priyatno, Kebijakan Legislasi Tentang Sistem Pertanggungjawaban Pidana Koorporasi Di Indonesia, Bandung: Cv. Utomo, (2004), pg. 15.

${ }^{17}$ Ibid. pg. 16
} 
that anything that has a relationship with issues that touch the press, the areas of law that must take precedence are press legislation and journalist regulations. Second, based on the Criminal Law Basis, it is stated that the act of implementing legislative provisions cannot be punished. The press is the bearer of the mandate of the Constitution and the Press Law, particularly Article 3 which contains the function of the press as public education and social control. Thus, press activity is the implementer of the law, so it cannot be convicted.

It is not the same as the philosophy of the Press Law as lex specialis, where journalists' activities cannot be subject to corporal punishment. In fact, at this time the legal philosophy of journalism as a law that has a specificity has received support from the Supreme Court of the Republic of Indonesia which in its consideration (ratio decidendi) states: "Philosophically, based on Article 3, Article 4 of the Press Law, the role of the national media is positioned as a government that upholds equal rights and obligations even though journalism legislation is still in a state of incapability of doing it places itself in a direction that is not limited by the rules for spreading news because it does not have legal power on that classification if the basic criminal law provisions are made, so placing journalists in a regulation is not just an imaginary". 18

Regarding the decision of the Supreme Court, it should be placed in the context of the Civil Law mechanism that we adhere to, namely that the decision is not a binding precedent, but only a persuasive precedent. This is in contrast to the Anglo Saxon legal mechanism which adheres to stare decicis or is also called the principle of the binding force of precedent, where previous Court Decisions must serve as guidelines for subsequent Court Decisions. Furthermore, in the context of the legal mechanism in Indonesia, this decision is not a binding legal basis and must always be followed in the next decision. If the response authority and methods to the news agency do not find common ground, then it is based on journalism legalization, handling something that is of course legal in a journalist's legalization.

Based on the results of the analysis of the above discussion, the legal settlement process for journalists who have been proven to have violated the provisions of the applicable law must have a clear basis, because it can have a detrimental impact on the parties whose reputation has been tarnished for untrue reporting.

\section{Efforts to Undergo as a Result of False News}

Journalists in carrying out their functions apart from being limited by legal provisions, such as Law Number 40 of 1999, must also adhere to the journalistic code of ethics. ${ }^{19}$ In the journalism field, there is a concept for the authority to respond and correct. These authorities can be used by the public if they feel aggrieved by the false of journalists in publishing news that cause disturbance. ${ }^{20}$

If there is a party that feels that it is directly injured by a reporter's report, then that party has the authority to respond in an effort to correct or rectify an article in a newspaper. The party may visit the newspaper or journalism commission.

The authority of the news commission is to convey the reasons for the estimation. Moreover, the authority takes over reports of the injured party regarding events related to the publication of news carried out by journalists. If they have evidence of adverse events in the

\footnotetext{
${ }^{18}$ Preety Bella Wajong, "PERLINDUNGAN HUKUM BAGI WARTAWAN DALAM MELAKSANAKAN TUGAS DAN FUNGSI TERKAIT DENGAN KEBEBASAN PERS MENURUT UNDANG-UNDANG NOMOR 40 TAHUN 1999," Lex Et Societatis, vol. VI, July 3, 2018, https://ejournal.unsrat.ac.id/index.php/lexetsocietatis/article/view/19954.

${ }^{19}$ Sirojul Rahman, "Kejahatan Pencemaran Nama Baik Atas Pemberitaan Pers Di Kota Palangka Raya," Restorica: Jurnal Ilmiah Ilmu Administrasi Negara Dan Ilmu Komunikasi 3, no. 1 (March 31, 2017): 134-39, https://doi.org/10.33084/restorica.v3i1.635.

${ }^{20}$ Padmo Wahyono, "Pembangunan Hukum Melalui Pers," Jurnal Hukum \& Pembangunan 18, no. 4 (June 19, 2017): 354, https://doi.org/10.21143/jhp.vol18.no4.1273.
} 
news, the concerned people can complain to the Press Council to raise objections to a journalist in the press report relating to the error in writing.

Problems caused by false news can lead to a legal process in the judiciary or through complaint to the authorities (the police). However, the process or system for handling journalist review problems has been recorded in the journalist's regulation which has the effect of justifying and revising. Thus, law enforcement agencies against criminal acts committed by journalists use the legal basis of journalism which derives from the authority of justification and revision. Resolution for news publication errors by the press can be strived by making a complaint at the Press Council. The next flow is the resolution for impacts as an impact of the false news, related parties will be asked as soon as possible to correct the mistakes that have been caused to the public.

Efforts that can be taken due to false news can be made through:

1) Integral Approach Theory

This theory explains law enforcement by the Press Council against journalists who report wrongly through an integral approach (openly) to journalists that aims on realizing law-abiding and professional journalists in publishing news.

2) Scientific Approach Theory

This theory explains law enforcement by the Press Council against journalists who report falsely through a scientific approach prioritizes communication and humanism from the Press Council. This aims to respect journalists as the spearhead a news publication.

This research is different from Bayu Herdianto (2011), this thesis describes that press coverage in a conflict case can have a conducive or destructive impact. It is conducive if the news is objectively produced which is able to provide a sense of peace related to the existing situation. It is destructive if the news causes problems.

\section{Closing}

\section{Conclusion}

If the elements of criminal acts committed by journalists have been fulfilled, then mechanism of legal responsibility for journalists who publish wrong news the form of legal responsibility is resolved through the mechanism of the Press Law by referring to the Press Council as the party given the authority by law. Enforcement of criminal law against journalists who make scientific publications are based on journalists that have violated provisions which are guidelines for writing news an caused impact on parties who are disadvantaged by the publication. Efforts that can be taken as a result of false news is through a complaint towards the Press Council and rectifying the wrong news which is followed by requests of highlighting news' inaccuracy aimed at the public.

\section{Advice}

This research provides suggestions:

a. The need for newspaper leaders to supervise the application of journalistic code of ethics to journalists and ensure it is implemented continuously in order to reduce journalists' actions of legal violations due to false reporting and upholding criminal acts.

b. Journalists need ethics in journalistic activities and in an orderly manner writing news (newspapers) in accordance with the facts without having to make news mistakes so that there is no legal crime. 
c. For the public to not hesitate in reporting false news to the Press Council if it is not in accordance with the truth, so required legal process aligned with the relevant regulation could be implemented effectively.

\section{BIBLIOGRAPHY}

\section{A. Book}

Priyatno, 2004. Kebijakan Legislasi Tentang Sistem Pertanggungjawaban Pidana Koorporasi Di Indonesia. Bandung: CV. Utomo

Chairul, 2006. Dari Tiada Pidana Tanpa Kesalahan Menuju Kepada Tiada Pertanggungjawaban Pidana Tanpa Kesalahan.Jakarta: Kencana Prenada Media

Maroni, 2012. Rekonstruksi Birokrasi Peradilan Pidana Berbasis Pelayanan Publik Untuk Mewujudkan Keadilan. Lembaga Program Pascasarjana Undip

Rifai Eddy, 2014. Perspektif Pertanggungjawaban Pidana Korporasi Sebagai Pelaku Tindak Pidana Korupsi.Mimbar Hukum-Fakultas Hukum Universitas Gadjah Mada

\section{B. Journal}

Abdul Halik, "ATMOSFER KEBEBASAN PERS (ANTARA HUKUM, ETIKA, DAN PROFESIONALISME WARTAWAN)," Jurnal Jurnalisa : Jurnal Jurusan Jurnalistik 6, no. 1 (June 3, 2020), https://doi.org/10.24252/JURNALISA.V6I1.13667.

Dahlan Surbakti, "PERAN DAN FUNGSI PERS MENURUT UNDANG-UNDANG PERS TAHUN 1999 SERTA PERKEMBANGANNYA Dahlan Surbaktil," Jurnal Hukum $\begin{array}{lllll}\text { PRIORIS, } & \text { vol. } & \text { May } & \text { 18, }\end{array}$ https://trijurnal.lemlit.trisakti.ac.id/prioris/article/view/396.

Iin Rahmawati and Ruslan Abdul Gani, "PERTANGGUNGJAWABAN PIDANA TERHADAP DELIK PERS (Suatu Kajian Normatif)," Legalitas: Jurnal Hukum 1, no. 4 (May 9, 2017): 133-90, http://legalitas.unbari.ac.id/index.php/Legalitas/article/view/74.

Indah Lestari and Sri Endah Wahyuningsih, "PENEGAKAN HUKUM PIDANA TERHADAP PENGGUNA NARKOBA DI POLDA JATENG," Jurnal Hukum Khaira Ummah 12, no. 3 (September 15, 2017): 601-10, http://jurnal.unissula.ac.id/index.php/jhku/article/view/1889.

Irman Syahriar, "FUNGSI PERS SEBAGAI PENYEBARAN INFORMASI DALAM PENEGAKAN HUKUM DI INDONESIA,” LEGALITAS 4, no. 2 (January 15, 2020): 19-35, https://doi.org/10.31293/LG.V4I2.4460.

Mufti Nurlatifah, "POSISI UNDANG-UNDANG PERS INDONESIA DALAM EKOSISTEM MEDIA DIGITAL," Profetik: Jurnal Komunikasi 11, no. 1 (April 29, 2018): 71, https://doi.org/10.14421/pjk.v11i1.1289.

Muhaimin Muhaimin, "Restoratif Justice Dalam Penyelesaian Tindak Pidana Ringan," Jurnal Penelitian Hukum De Jure 19, no. 2 (June 26, 2019): 185, https://doi.org/10.30641/dejure.2019.v19.185-206.

Nur Aisyah Siddiq, "PENEGAKAN HUKUM PIDANA DALAM PENANGGULANGAN BERITA PALSU (HOAX) MENURUT UNDANG-UNDANG NO.11 TAHUN 2008 YANG TELAH DIRUBAH MENJADI UNDANG-UNDANG NO.19 TAHUN 2016 TENTANG INFORMASI DAN TRANSAKSI ELEKTRONIK," LEX ET $\begin{array}{lllll}\text { SOCIETATIS, } & \text { vol. } & 5, & \text { December } & 22,\end{array}$ https://ejournal.unsrat.ac.id/index.php/lexetsocietatis/article/view/18485. 
Padmo Wahyono, "Pembangunan Hukum Melalui Pers," Jurnal Hukum \& Pembangunan 18, no. 4 (June 19, 2017): 354, https://doi.org/10.21143/jhp.vol18.no4.1273.

Preety Bella Wajong, "PERLINDUNGAN HUKUM BAGI WARTAWAN DALAM MELAKSANAKAN TUGAS DAN FUNGSI TERKAIT DENGAN KEBEBASAN PERS MENURUT UNDANG-UNDANG NOMOR 40 TAHUN 1999," Lex Et $\begin{array}{lllll}\text { Societatis, } & \text { vol. } & \text { VI, } & \text { July } & \text { 3, 2018, }\end{array}$ https://ejournal.unsrat.ac.id/index.php/lexetsocietatis/article/view/19954.

Raden Muhamad and Ibnu Mazjah, "TANGGUNGJAWAB PERS NASIONAL SEBAGAI SUBJEK HUKUM PIDANA DALAM PERSPEKTIF TANGGUNGJAWAB KORPORASI," Raden Muhamad Ibnu Mazjah Tanggungjawab Pers Nasional..., vol. 16, July 3, 2018, https://journal.untar.ac.id/index.php/hukum/article/view/4527.

Sandy Prasetya Makal, Syamsul Haling, and Andi Purnawati, "PERTANGGUNGJAWABAN PIDANA PELAKU TINDAK PIDANA PERS BERDASARKAN HAK JAWAB (STUDI KASUS DUA PUTUSAN PENGADILAN) CRIMINAL LIABILITY FOR CRIMINAL ACTS OF THE PRESS UNDER THE RIGHT OF RESPONSIBILITY (CASE STUDY OF TWO COURT JUDGMENTS)," Jurnal Kolaboratif Sains, vol. 1, September 15, 2019, https://doi.org/10.31934/JOM.V1I1.931.

Sigit Surahman and Fuqoha Fuqoha, "MEKANISME PENYELESAIAN PELANGGARAN KODE ETIK JURNALISTIK PADA DEWAN PERS DI KOTA SERANG," LONTAR: Jurnal Ilmu Komunikasi 5, no. 2 (December 29, 2017): 51-64, https://doi.org/10.30656/lontar.v5i2.491.

Sirojul Rahman, "Kejahatan Pencemaran Nama Baik Atas Pemberitaan Pers Di Kota Palangka Raya," Restorica: Jurnal Ilmiah Ilmu Administrasi Negara Dan Ilmu Komunikasi 3, no. 1 (March 31, 2017): 134-39, https://doi.org/10.33084/restorica.v3i1.635.

Triya Indra Rahmawan, "KARAKTERISTIK PRODUK HUKUM PERS DAN PROSPEK KONSOLIDASI DEMOKRASI," WASKITA: Jurnal Pendidikan Nilai Dan Pembangunan Karakter 2, no. 2 (July 1, 2017): 1-16, https://doi.org/10.21776/ub.waskita:jurnalpendidikannilaidanpembangunankarakter.20 18.002.02.1. 
